\title{
Nine species from Madagascar are moved from Vernonia to Distephanus (Compositae, Vernonieae)
}

\author{
Vicki A. Funk', Harold Robinson' \\ I Department of Botany, MRC 166, National Museum of Natural History, Smithsonian Institution, Washing- \\ ton, DC. 20023-7012, USA \\ Corresponding author: Vicki A. Funk (funkv@si.edu)
}

Academic editor: A. Sennikov | Received 6 January 2017 | Accepted 8 February 2017 | Published 17 March 2017

Citation: Funk VA, Robinson H (2017) Nine species from Madagascar are moved from Vernonia to Distephanus (Compositae, Vernonieae). PhytoKeys 77: 89-92. https://doi.org/10.3897/phytokeys.77.11727

\begin{abstract}
The genus Distephanus is native to Madagascar, the Mauritius, central and southern Africa, Yemen (Socotra Island), and China. The majority of the diversity is found in Madagascar. Here we provide new combinations for nine species of Vernonia that belong in Distephanus, all from Madagascar. All of the species were formerly placed in the large genus Vernonia, now greatly reduced.
\end{abstract}

\section{Keywords}

Asteraceae, Asterids, flowering plants, Madagascar, Vernonia

\section{Introduction}

As we continue to emerge from the "Dark Ages of Lumping" it should come as no surprise to any student of the Compositae that morphological and molecular data are being used (separately and together) to address generic limits. As a result we are seeing the breakup of many large non-monophyletic genera. In one such case, the genus Vernonia Schreb., of the tribe Vernonieae, has shrunk to about 20 species from North America and the remaining 1000 or so species from that genus are in the process of being assigned to other genera. Many of these "new" genera were previously described and subsequently sunk into Vernonia, but others needed new names and descriptions. An overview of the tribe was presented by Keeley and Robinson (2009) and major overhauls have taken place for the Americas (Robinson 1999), China (Robinson and 
Skvarla 2010), Thailand (Bunwong et al. 2014) and Southern Africa (Swelankomo and Manning 2014; Robinson et al. 2016). Still awaiting work are the Vernonieae of Madagascar, tropical Africa, India, and SE Asia.

As part of a larger more comprehensive work on the Vernonieae of Madagascar this effort concerns the establishment of proper limits for the genus Distephanus Cass. Described by Cassini based on a type removed from Conyza (Astereae), Distephanus has long been recognized as distinctive (trees, shrubs or woody vines; yellow or orange flowers; tri-nervate leaf venation) even when it was considered part of Vernonia (herbs or subshrubs; purple, pink or white flowers; pinnate leaf venation). In addition to the type species three other species were described in Distephanus and therefore do not need to be transferred and a number of combinations have already been made: 24 by Robinson and Kahn (1986), one by Robinson (2009), two by Robinson (2012), one by Robinson and Funk (in Funk et al. 2012) and one by Boon and Glen (2013) for a total of 33 species currently in Distephanus. However, because of a lack of available herbarium material some of the Madagascar species names were left as Vernonia. After examining herbarium material from the Muséum National d'Histoire Naturelle (P), nine additional combinations can now be made. The following combinations are needed at this time because of upcoming entries in GenBank and determinations on specimens from a recent field trip in September-October of 2016. Descriptions and synonomy can be found in Humbert (1960: Volume 1, 121-171). With these additions, the number of species in Distephanus now stands at 42 with possible new species to be described based on material collected during the aforementioned field trip.

\section{Vernonia species from Madagascar transferred into Distephanus}

Distephanus bakeri (Vatke) V.A.Funk \& H.Robinson, comb. nov. urn:Isid:ipni.org:names:77161439-1

Vernonia bakeri Vatke. Bremen Abh. Natuewiss. Vereins Bremen 9: 119. 1885.

Distephanus capuronii (Humbert) V.A.Funk \& H.Robinson, comb. nov. urn:Isid:ipni.org:names:77161440-1

Vernonia capuronii Humbert, Mem. Inst. Sci. Madagascar, Sér. B., Bíol. Veg. 6: 152. 1955.

Distephanus grevei (Drake) V.A.Funk \& H.Robinson, comb. nov. urn:Isid:ipni.org:names:77161442-1

Vernonia grevei Drake. Bull. Soc. Bot. France 46: 240. 1900 [dt. 1899; publ. early1900] 
Distephanus ibityensis (Humbert) V.A.Funk \& H.Robinson, comb. nov. urn:lsid:ipni.org:names:77161443-1

Vernonia ibityensis Humbert, Notul. Syst. (Paris) 13(4): 313. 1949 [dt. Apr 1948; publ. early 1949]

Distephanus poissonii (Humbert) V.A.Funk \& H.Robinson, comb. nov. urn:lsid:ipni.org:names:77161444-1

Vernonia poissonii Humbert, Notul. Syst. (Paris) 8(1): 6. 1939.

Distephanus polytricholepis (Baker) V.A.Funk \& H.Robinson, comb. nov. urn:lsid:ipni.org:names:77161445-1

Vernonia polytricholepis Baker, J. Linn. Soc., Bot. 21: 415. 1885

Distephanus quartziticola (Humbert) V.A.Funk \& H.Robinson, comb. nov. urn:lsid:ipni.org:names:77161446-1

Vernonia quartziticola Humbert, Notul. Syst. (Paris) 13(4): 305.1949 [dt. Apr 1948; publ. early 1949]

Distephanus rhodopappus (Baker) V.A.Funk \& H.Robinson, comb. nov. urn:lsid:ipni.org:names:77161447-1

Vernonia rhodopappa Baker. J. Linn. Soc., Bot. 22: 487. 1887

Distephanus spiciformis (Klatt) V.A.Funk \& H.Robinson, comb. nov. urn:lsid:ipni.org:names:77161448-1

Vernonia spiciformis Klatt. Ann. Nat. Hofmus. Wien 7: 296. 1892

\section{Acknowledgements}

We thank the Muséum National d'Histoire Naturelle (P) for assistance during the work in the herbarium in Paris, as well as the staff of the Missouri Botanical Garden (MO) in Madagascar and $\mathrm{P}$ for their assistance in setting up and executing the field trip. We also 
appreciate the comments from two reviewers and the subject editor. As usual we made use of the IPNI website (http://www.ipni.org) and we thank Kanchi Gandhi (GH) for helping us locate the actual publication dates of some original literature.

\section{References}

Boon R, Glen HF (2013) Distephanus (Asteraceae: Vernonieae): a new combination and a new record for southern Africa. Bothalia 43(1): 94-96. https://archive.org/stream/bothaliavolume4343unse/bothaliavolume4343unse_djvu.txt

Bunwong S, Chantaranothai P, Keeley SC (2014) Revision and key to the Vernonieae of Thailand. Phytokeys 37: 25-101. https://doi.org/10.3897/phytokeys.37.6499

Funk VA, Kelloff C, Chan R (2012) Phylogeny and Biogeography of the Tribe Liabeae (Compositae; subfamily Cichoroideae). Taxon 61: 437-455. https://www.researchgate.net/publication/247150678_Phylogeny_and_Biogeography_of_the_Tribe_Liabeae_Compositae_ subfamily_Cichoroideae

Humbert H (1960) Flore de Madagascar et des Comores. 189 ${ }^{\mathrm{e}}$ Famille - Composees, vol. 1. Typographie Firmin-Didot, Paris. http://biodiversitylibrary.org/page/8108583

Keeley SC, Robinson H (2009) Vernonieae. In: Funk VA, Susanna A, Stuessy TF, Bayer RJ (Eds) Systematics, Evolution, and Biogeography of Compositae. International Association for Plant Taxonomy, Vienna, 439-469.

Robinson H, Kahn B (1986) Trinervate leaves, yellow flowers, tailed anthers, and pollen variation in Distephanus Cassini (Vernonieae: Asteraceae). Proceeding of the Biological Society of Washington 99: 493-501. https://doi.org/10.1098/rspb.1986.0036

Robinson H (1999) Generic and Subtribal classification of American Vernonieae. Smithsonian Contributions to Botany 89: 1-116. https://doi.org/10.5962/bhl.title.103697

Robinson H (2009) The generic disposition of the African Vernonia biafrae Oliv. \& Hiern. (Vernonieae: Asteraceae). Phytologia 91(3): 534-536. http://biodiversitylibrary.org/page/28528804

Robinson H, Skvarla JJ (2010) Genera of the Vernonieae (Asteraceae) of China with a study of their pollen. Taiwania 55(3): 254-272. https://doi.org/10.6165/tai.2010.55(3).254

Robinson H, Skvarla JJ, Funk VA (2016) Vernonieae (Asteraceae) of Southern Africa: A generic disposition of the species and a study of their pollen. Phytokeys 60: 49-126. https://doi. org/10.3897/phytokeys.60.6734

Robinson H (2012) Two new combinations in the genus Distephanus Cass. (Asteraceae, Vernonieae). PhytoKeys 17: 25-26. https://doi.org/10.3897/phytokeys.17.4013

Swelankomo N, Manning JC (2014) The genus Distephanus (Asteraceae: Vernonieae) in southern Africa. South African Journal of Botany 94: 238-248. https://doi.org/10.1016/j. sajb.2014.07.007 